Virgilio Galdo, Gladys Lopez Acevedo* and Martin Rama

\title{
Conflict and the composition of economic activity in Afghanistan
}

\begin{abstract}
Despite informality being the norm in conflict-affected countries, most estimates of the impact of conflict on economic activity rely on formal sector data. Using high-frequency data from Afghanistan, this paper assesses how surges in conflict intensity affect not only the formal sector, but also informal and illicit activities. Nighttime light provides a proxy for aggregate economic activity, mobile phone traffic by registered firms captures fluctuations in formal sector output, and the land surface devoted to poppy cultivation gives a measure of illicit production. The unit of observation is the district and the period of reference is 2012-2016. The results show that an increase in conflict-related casualties has a strong negative impact on formal economic activity in the following quarter and a positive effect on illicit activity after two quarters. The impact on aggregate economic activity is negative, but more muted.
\end{abstract}

$\begin{array}{ll}\text { Current version: } & \text { July } 08,2021 \\ \text { Keywords: } & \text { Afghanistan, conflict, economic activity } \\ \text { JEL codes: } & \text { D74, E21, F35, I32, O17 } \\ \text { Corresponding author: } & \text { Gladys Lopez-Acevedo } \\ & \text { gacevedo@worldbank.org }\end{array}$

All author are with The World Bank. Email:vgaldo@worldbank.org; mrama@worldbank.org

(c) The Author(s). 2021. Open Access This article is distributed under the terms of the Creative Commons Attribution 4.0 International License (http://creativecommons.org/licenses/by/4.0/), which permits unrestricted use, distribution, and reproduction in any medium, provided you give appropriate credit to the original author(s) and the source, provide a link to the Creative Commons license, and indicate if changes were made. @- Cite as: Lopez-Acevedo. IZA Journal of Development and Migration (2021) 12:10 


\section{Introduction}

Conflict can affect a country's development through various channels, including the loss of physical and human capital, the disruption of production processes, and the undermining of markets (Blattman and Miguel, 2010). Not surprisingly, the empirical evidence available shows a negative correlation between economic activity and conflict intensity.

Estimates of the impact of conflict on aggregate economic activity differ in their magnitude, but they are all negative and sizeable. De Groot et al. (2015) claim that global gross domestic product (GDP) would have been 15.7\% higher in 2007, had there been no conflict since 1960. According to Collier (1999), civil wars result in a 2.2\% decline in GDP per capita annually, primarily because of slow production but also due to the loss of capital. Similarly, Acemoglu et al. (2011) find that cities that suffered the Holocaust most intensely have grown less since then, and that administrative districts where the Holocaust had the largest impact have lower GDP per capita and lower average wages today. And Singh (2013) reports that Punjab districts experiencing a major terrorist incident saw their long-term fixed investment decline by around $17 \%$.

A more recent literature has relied on detailed microeconomic data, rather than on aggregate GDP, average wages, or fixed investment. Again, the estimated impact is unambiguously negative. For example, Besley and Mueller (2012) show that house prices in Northern Ireland declined with conflict-related killings. And Blumenstock et al. (2018) report that mobile phone traffic by formal firms in Afghanistan fell when conflict-related casualties increased.

However, the data used in these analyses - both aggregate and disaggregate - are mostly from the formal sector of the economy. This is despite informality being prevalent in developing countries affected by conflict. Institutions are most often weak in these countries, and enforcement is ineffective. Households usually engage in subsistence agriculture or selfemployment, whereas firms are small and have low capital intensity. Illicit activities, including drug production and commercialization, are common.

The goal of this paper is to offer an integrated assessment of the change in formal, informal, and illicit economic activity in response to surges in conflict. The analysis is for Afghanistan, a country that has been repeatedly at war (World Bank, 2020). The focus is on the period starting in 2012, at a time when the intensity of conflict increased dramatically, after a decade of relative stability and rapid economic growth.

The analysis relies on high-frequency data from non-traditional sources of information to measure economic activity. Satellite imagery allows us to assess nighttime light intensity for "tiles" measuring just one square kilometer. Remote sensing by satellites is also informative on the land surface devoted to the cultivation of poppies in every season. And anonymized cell phone traffic data from several thousand registered firms have been made available by a major telephone operator.

These non-traditional sources of information make it possible to conduct rigorous empirical analyses despite the obvious shortcomings of official statistical systems in conflict-affected countries. It has been shown that nighttime light intensity is highly correlated with GDP in developing countries (Donaldson and Storeygard, 2016, Henderson et al., 2012). In South Asia, this high correlation holds even at the subnational level (Beyer et al., 2018). It has also been 
documented that data from mobile phone records can be exploited to understand a large array of social phenomena from land use to wealth and asset distribution to traditional measures of firm activity (Pei et al., 2014, Blumenstock et al., 2015, Blumenstock et al., 2018), among others. And the land surface devoted to poppy cultivation has already been used as a direct measure of the size of illicit activities (Lind et al., 2014).

While there is no readily available data source to assess economic fluctuations in the informal sector, these can be inferred from the other high-frequency series considered. Aggregate output is the sum of output by the formal, informal, and illicit sectors, and there is a sense of the relative weight of these sectors in Afghanistan's economy in recent years. It is thus relatively straightforward to estimate the change in informal sector activity as a weighted difference between the change in nighttime light intensity and the change in cell phone traffic among registered firms.

Non-traditional sources of information are also used to measure the intensity of conflict at the local level, and to control for potentially confounding circumstances. The US Pentagon has made available data on conflict-related casualties with a high level of spatial disaggregation, as well as information on the presence of international and Afghan troops at the district level. Based on information from international donor agencies, it is also possible to estimate the level of foreign aid at the district level.

The high frequency of the data also allows estimating the response of each of the three sectors to conflicts with varying time lags. In this paper, the impacts from conflict are estimated over each of the four quarters following a surge in the number of casualties. The exercise reveals very different time patterns across sectors. The impact of local surges in conflict on overall economic activity is relatively modest, but their effect on the composition of output is dramatic.

\section{The Afghan Context}

Following the fall of the Taliban regime in 2001, Afghanistan received massive international security and development assistance. More than 100,000 international troops were stationed in the country until 2012, supporting operations against the ongoing insurgency and assisting in building and training a national defense force. To ensure a path toward self-reliance, the government of Afghanistan and NATO partners agreed in 2010 on a gradual handover of security responsibilities. By 2018, there were only 16,229 international troops in Afghanistan. ${ }^{1}$ There was also a substantial decline in military and civilian aid, from $90 \%$ of GDP in 2009 to $44 \%$ in 2018.

The withdrawal of international troops and security forces has been associated with a steady increase in conflict-related casualties. The number of civilians who died or were injured because of the conflict surged from 5,969 in 2009 to 10,993 in 2018 (Figure 1A). Violence remains heavily concentrated in the western and southern parts of the country, but the northern region has also experienced a substantive increase in the number of civilian casualties (Figure 1B).

1 See NATO (2018) Resolute Support Mission “placemat” as of November 2018. https://www.nato.int/nato_static_fl2014/ assets/pdf/pdf_2018_11/20181112_2018-11-RSM-Placemat.pdf. 
Figure 1 Conflict-related casualties and injured in Afghanistan. (A) Casualties and injured over time. (B) Casualties and injured across space.

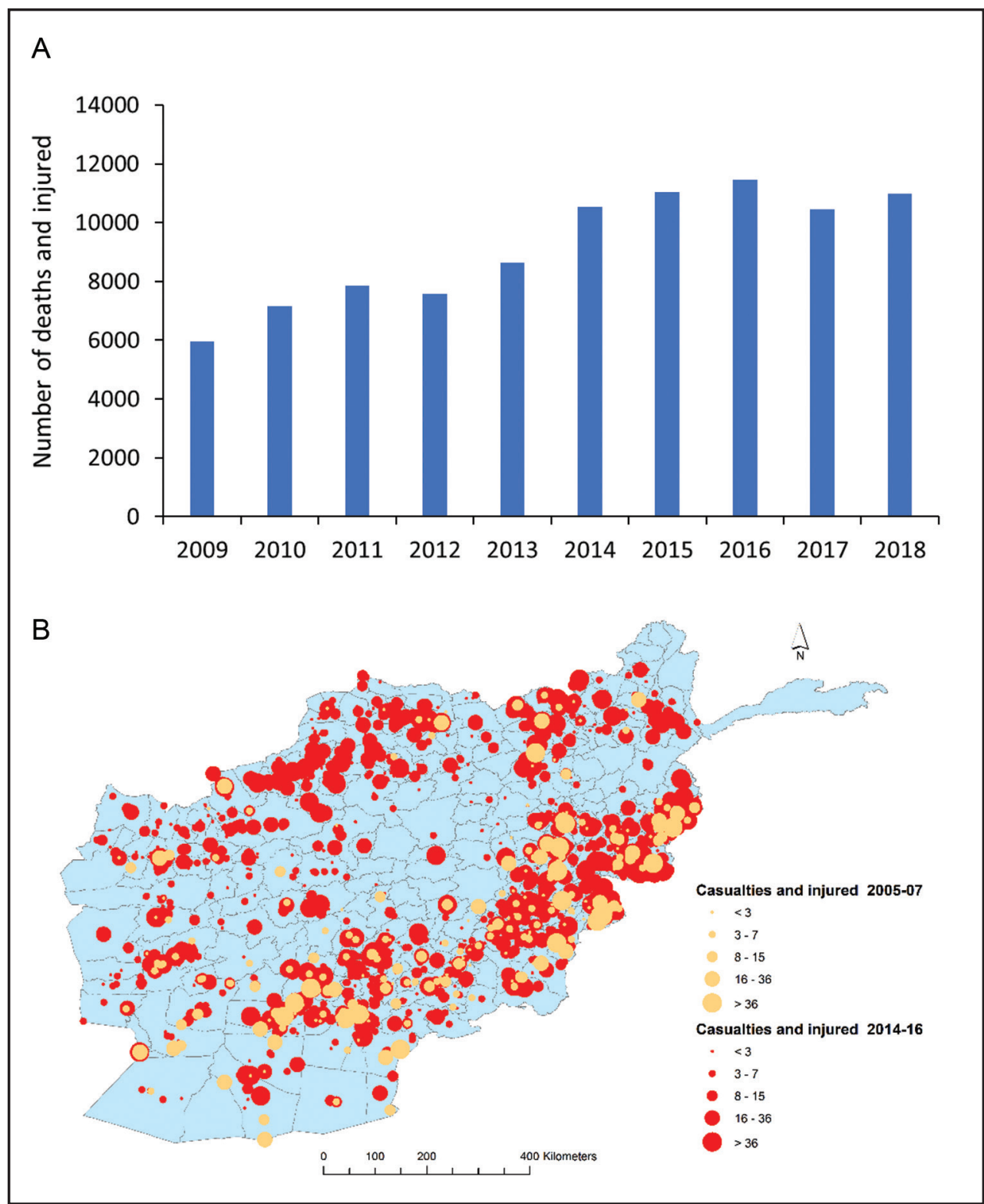

Source: Author's calculations based on UNAMA (2019) and GTD (2016). GTD, global terrorism database.

The withdrawal of international troops and the decline in foreign aid adversely affected consumer and investor confidence and resulted in a sharp decline in domestic demand. New firm registrations fell by almost half between 2012 and 2016, across most sectors (Figure 2A). The growth rate of GDP declined from an average of nearly 11\% per year between 2007 and 2012 to barely $2.1 \%$ by 2016 . (Figure $2 \mathrm{~B}$ ).

\section{Previous Research}

The available evidence on association of conflict and economic activity is diverse in nature. Of the 42 studies reviewed for this paper, 20 assess impacts on aggregate economic activity and 12 focus exclusively on the formal sector of the economy. Only seven of the 42 studies 
Figure 2 Economic activity in Afghanistan. (A) Firm registration by sector. (B) GDP growth rates by sector.

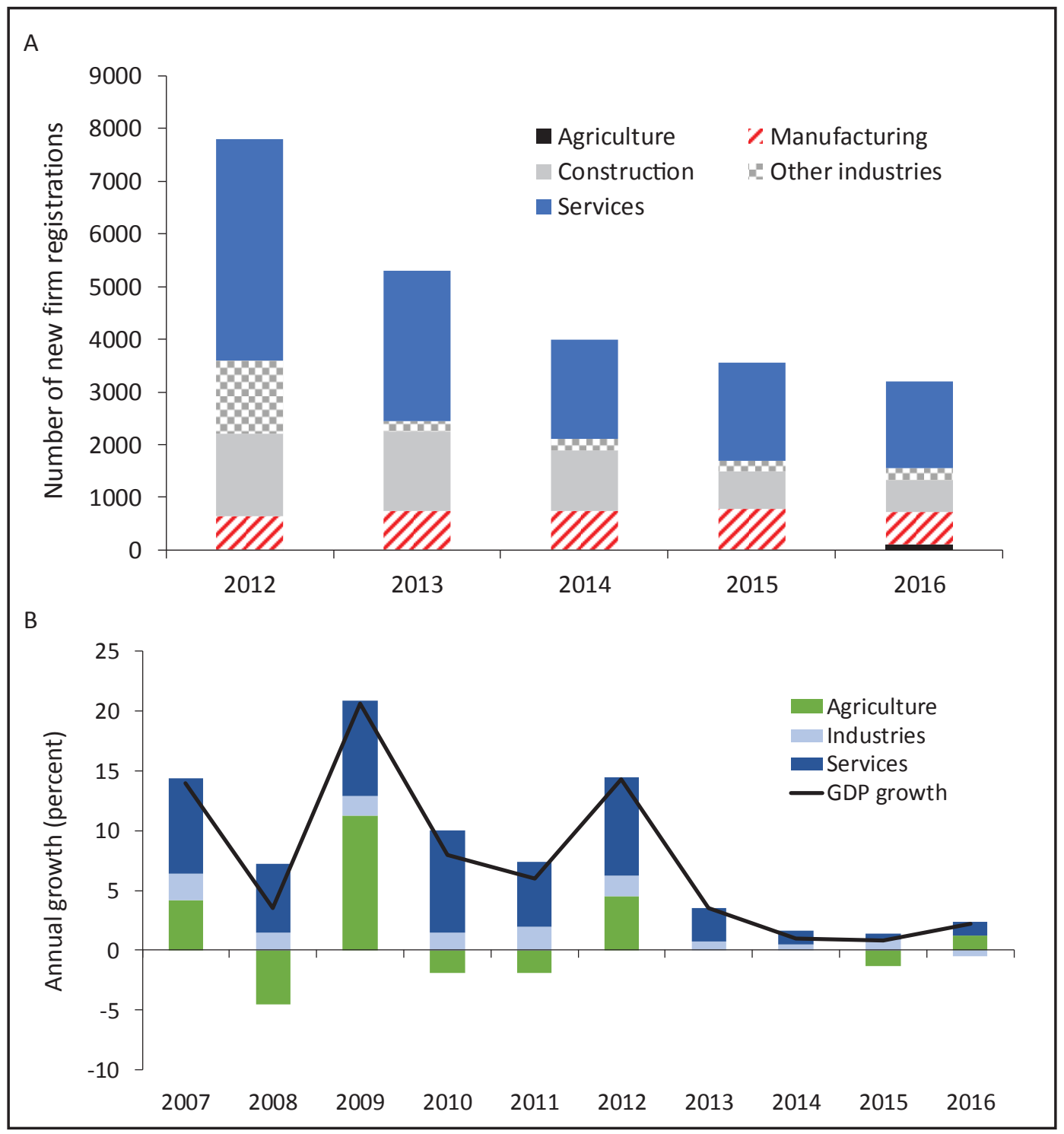

Source: World Bank (2018). GDP, gross domestic product.

deal with the impact of conflict on illicit activities, with only three of them focusing on the informal sector.

These seven studies shed some light on the nature and channels of association between conflict and illicit activities. Studying the emergence and evolution of drug economy against the backdrop of Afghanistan's transforming political economy, Goodhand (2008) highlights that the tendency of drugs to produce conflict depends upon underlying power relations and argues that in parts of Afghanistan drugs have contributed to some degree of political order. Even Stepanova (2012) suggests that that relation between conflict-related violence and drugs is non-linear and argues that the war of the US-led coalition on the Taliban did not significantly reduce Afghanistan's opium economy. Lind et al (2014) found that conflict causes more opium production even when the farmgate price of opium declined during the study period by changing incentives; rising conflicts hamper infrastructure for other crops and by increasing perceived lawlessness also raise profits from high-risk illegal opportunities. The paper by Keohler and Zuercher (2007) reveals that the channel through which poppy shaped violence is 
by increasing competition via credit and land; high profits from poppy cultivation increased the value of land and high interest rates of credit induced more farmers to take up poppy over other crops given its higher profits.

Three of the papers also suggest that the response of informal activities to conflict is more muted than that of the formal sector. For example, Looney (2006) claims that the only part of the Iraqi economy to have survived both Saddam Hussein and the subsequent period of instability and insurgency was the country's informal economy. In the Afghanistan context, Ciarli et al. (2015) show that the probability that a household engages in self-employment activities with low capital intensity, or in subsistence agriculture, increases with surges in conflict. Lastly, Berman et al. (2013) using data from Philippines found that increased investment is positively associated with violence providing evidence for predation by insurgents/rebels and tax capture by government. These studies highlight that the impact of conflict could even be positive in the case of illicit activities.

From a methodological point of view, three studies in the literature on the impact of conflict on economic activity are especially relevant for the exercise in this paper. These studies deal with the impact on aggregate output, on the formal sector and on illicit activities, respectively. Differences in the approaches used in each case provide a useful backdrop to guide the empirical work for Afghanistan.

At the aggregate level, Abadie and Gardeazabal (2003) use a quasi-difference-indifferences approach to assess the impact of terrorism on the GDP per capita of the Basque Country from 1955 to 1977. To do so they construct a "synthetic control region", as a weighted combination of other Spanish regions. The economic evolution of this synthetic control region without terrorism is compared to the actual experience of the Basque Country using an autoregressive distributed lag model.

The gap $\Delta Y$ per capita GDP between treatment and control is the dependent variable in the analysis, and the number $C$ of fatalities from terrorism (almost 800 over time) is the independent variable. The study estimates the impulse-response function to conflict assuming that the output gap $\Delta Y$ year $t$ determined by the number of deaths from terrorism $C$ both in the same year and in the two previous years, as well as by the output gap in the two previous years:

$$
\Delta Y_{t}=\beta+\sum_{k=0}^{2} \mu^{k} C_{t-k}+\sum_{k=1}^{2} \theta^{k} \Delta Y_{t-k}+u_{t} .
$$

The error term $u_{t}$ in this equation is assumed to follow a first-order auto-regressive model. Therefore, the parameters in Eq. (1) are estimated using data on conflict and the output gap lagged for up to 3 years. No other control variables are considered in the proposed specification.

The results reveal a negative impact of deaths from terrorism in the previous year, but not in the same year or 2 years earlier $\mu^{1}$ (statistically significant but $\mu^{0}$ and $\mu^{2}$ are not). Based on the estimated coefficients, after the outbreak of terrorism, per capita GDP in the Basque Country declined about 10 percentage points relative to the synthetic control region.

Impacts on the formal sector are assessed by Blumenstock et al. (2018), who investigate how private sector firms in Afghanistan respond to changes in the local security situation. Whether the firms are active is assessed based on call detail records from one of the country's largest mobile network operators between April 2013 and December 2016 spanning two-thirds 
of the country's districts. In parallel, more than 100 major violent events are identified and geocoded based on the Global Terrorism Database (GTD).

The study estimates a dynamic specification linking the number of firms $Y^{F}$ active in district $i$ and month $t$ to the number of major violent events $C$ in that district, over a 12 -month period spanning a quarter before the event and three quarters afterward:

$$
\operatorname{Ln} Y_{i t}^{F}=\beta+\sum_{k=-3}^{8} \mu^{k} C_{i, t-k}+\delta_{i}+\tau_{t}+\gamma_{i} t+\theta_{d} t^{2}+\varepsilon_{i t}
$$

The specification includes fixed effects for districts $\left(\delta_{i}\right)$ and months $\left(\tau_{t}\right)$ as well as a quadratic time trend at the district level. It does not include other control variables.

The results show no impact in the 3 months preceding the violent event. The number of active firms falls by $4.9 \%$ in the month of the event, with the decline growing to $6 \%$ in the following month and persisting for up to 5 months. Six months after the event the impact becomes statistically insignificant. A more disaggregated analysis shows that larger firms are more responsive to violence.

As for illicit activities, Lind et al. (2014) explore how the intensity of conflict in Afghanistan changes the incentives faced by farmers and spurs opium production. Poppies are more drought-resistant than wheat, the main alternative crop. They also take little space relative to their value and can easily be transported off roads. The destruction or disabling of irrigation and transportation networks resulting from conflict therefore makes poppies relatively more profitable than wheat.

Given lack of data on combat activities, the study bases its measure of conflict on the number of casualties from hostile encounters involving either NATO International Security Assistance Force (ISAF) forces or US forces participating in Operation Enduring Freedom (OEF) but excludes Afghan Casualties. The study argues that international forces tend not to be involved in anti-narcotic actions, implying that the chosen conflict indicator is plausibly exogenous to opium poppy production.

The main specification used in the empirical analysis links opium production $Y^{O}$ in district $i$ and year $t$ to both the contemporary and lagged values of a dummy variable $C$ indicating whether there were casualties in the locality:

$$
Y_{i t}^{O}=\beta+\sum_{k=0}^{2} \mu^{k} C_{i, t-k}+\delta_{i}+\tau_{t}+\varepsilon_{i t}
$$

The specification includes fixed effects for districts $\left(\delta_{i}\right)$ and years $\left(\tau_{i}\right)$. The results show a mild impact of conflict on poppy cultivation in the same year, a strong impact in the following year, and an insignificant effect 2 years later. The results also hold after instrumenting the intensity of conflict using data on local rainfall. However, the effect is not significant for conflict taking place after the planting season, and it is weaker in districts with better law enforcement.

\section{Methodology}

The methodology in this paper builds on a combination of the approaches in the three studies reviewed above. Like all three of them, the estimation relies on a temporal structure to capture dynamic effects, and it measures the intensity of conflict through the number of casualties associated with it. As in the studies on Afghanistan by Blumenstock et al. (2018) 
and by Lind et al. (2004), the geographic unit of observation is the district. And data are organized by quarters, keeping in mind that the planting season for poppies is between the months of November and December, or the fourth quarter in the calendar year.

At the same time, the paper innovates relative to these three studies, in several ways. First, instead of a single dependent variable for the analysis there are now three of them, aimed at capturing aggregate economic activity $Y^{A}$ formal sector output $Y^{F}$ and illicit production $Y^{O}$, respectively. Conceptually, these three variables verify:

$$
Y^{A}=Y^{F}+Y^{I}+Y^{O}
$$

where $I$ stands for informal sector activity.

The second innovation is to use a richer set of controls in the estimation, in addition to the lagged values of the conflict indicator, and district- and time-specific fixed effects. A recent study by Floreani et al. (2016) shows that living standards in Afghanistan are affected by conflict not only directly, through increased violence, but also indirectly, through the presence of troops and the volume of foreign aid directed to the locality. While the direct effect is negative, the indirect effect is positive. Given that troops and aid are allocated in response to the insurgency, the paradoxical result is that living standards are higher in conflict-affected districts. Not including as controls the presence of troops and the level of foreign aid at the local level would therefore result in biased estimates.

With these two innovations, the specification used in the empirical analysis is:

$$
L n Y_{i t}^{j}=\beta^{j}+\sum_{k=1}^{4} \mu_{k}^{j} C_{i, t-k}+\theta^{j} T_{i, t-1}^{W}+\delta^{j} T_{i, t-1}^{A}+\gamma^{j} D_{i, t-1}+\delta_{i}^{j}+\tau_{t}^{j}+\varepsilon_{i t}^{j}
$$

where $j \in\{A, F, O\}$ indicates the level at which the economic activity indicator is defined, $i$ are districts, $t$ are quarters, $T^{W}$ are international troops, $T^{A}$ are Afghan troops, and $D$ is the volume of foreign aid received at the local level. International troops and Afghan troops are entered separately in the specification as their impact on local economic activity may be different, possibly due to the different extents to which they procure supplies locally (Floreani et al., 2016). The specification also includes fixed effects for districts $\left(\delta_{i}\right)$ and quarters $\left(\tau_{i}\right)$ Eq. (5) can be estimated by Ordinary Least Squares (OLS) provided that the right-hand side variables are exogenous. The identifying assumption is that the conflict variable is independent from economic activity after conditioning on location fixed effects, time fixed effects, the presence of combat troops, and the level of international assistance. The irregular nature of Afghanistan's warfare gives support to this assumption (Ciarli et al., 2015). While a deterioration of the overall security situation could be anticipated as the international presence was scaled down, where exactly conflict would unfold is much more difficult to predict (Bazzi et al., 2019). This uncertainty over security risks makes local surges in conflict plausibly exogenous from the point of view of the empirical analysis. The OLS estimation is conducted with district clustered standard errors. Because the indicators for troops and aid are measured at the province level, and not at the district level as the indicators for economic activity and conflict are, estimates of Eq. (5) using robust standard errors are also reported to check how much of the significance is reliant on the clustering choice.

The chosen identification strategy is complemented with a series of placebo exercises testing whether a surge in casualties leads to a decline in economic activity. To do so, Eq. (5) is estimated with conflict leads rather than lags. 
Finally, using the same dynamic specification to estimate the impact of conflict on each of the three dependent variables allows a more rigorous comparison of the time structure of effects across sectors. And building on Eq. (4) it is also possible to estimate, in a comparable manner, the dynamic impact of conflict on informal sector activity as follows:

$$
y^{I}=y^{A}-\alpha^{F} y^{F}-\alpha^{O} y^{O},
$$

where lowercase variables indicate relative change, $\alpha^{F}$ is the estimated share of the formal sector in aggregate economic activity, and $\alpha^{0}$ is the corresponding share for the illicit economy.

In Afghanistan the informal sector has been estimated to account for $72 \%$ of total economic activity, with another $16 \%$ of it originating from illicit businesses (World Bank, 2005; SIGAR, 2018). These estimates are used in what follows for $\alpha^{F}$ and $\alpha^{0}$ respectively.

\section{Data}

The model is estimated using non-traditional data from a variety of sources, most of which are extraneous to the Afghan official statistical system. This approach is consistent with a broader trend to rely on big data to generate finely granular high-frequency estimates of otherwise conventional economic variables. The analysis is conducted with the district as the unit of observation, as this is the lowest level of spatial disaggregation for which all the relevant data are available. The estimates are for the period 2012-16. The initial year is the starting point of a rapid deterioration of the security situation in Afghanistan and the earliest year for which data is available for most of our outcome variables. The final year is the last one for which the Pentagon made spatially disaggregated data on conflict-related casualties available.

\subsection{Aggregate economic activity}

A stable relationship has been shown to exist between aggregate economic activity $Y^{A}$ and the sum of nighttime light per area. Global level estimates suggest that a $1 \%$ increase in nighttime light is associated with $0.267 \%$ increase in economic activity (Henderson et al., 2012). For South Asian countries the increase in economic activity has been estimated at $0.248 \%$, quite close to the global figure (World Bank, 2017). Building on these results, it is assumed in what follows that the elasticity of aggregate economic activity to nighttime light is 0.25 . This elasticity implies that the relative change in economic activity $y^{A}$ is only a quarter of the relative change in nighttime light.

The raw nighttime light data are derived from the VIIRS-DNB Cloud Free Monthly Composites, version 1, made publicly available by the Earth Observation Group at the National Geophysical Data Center of the National Oceanic and Atmospheric Administration (NOAA).

The data is far from perfect but in the context of absence of official statistics, it is still a reliable alternative. Previous analysis of the old DMSP-OLS night light product suggested indeed that nighttime lights mostly capture streetlights (Min et al., 2013). This study attenuates this problem, at some extent, by relying on data from a new satellite sensor with superior range of light detection and improved resolution, but it also comes with much variability over time and it is only available only shorter span of years. 
The released VIIRS-DNB data are already adjusted to correct for saturation, blooming effects, and comparability, all issues that had been detected in a previous nighttime lights product known as DMSP-OLS. The data are further cleaned for this paper, taking advantage of the 2015 annual composite of stable VIIRS nighttime lights to define a background noise mask (Elvidge et al., 2017). Only cells lying outside this background noise mask are treated as stable lights, while those inside the mask are recoded with value zero, corresponding to no light. The VIIRS-DNB data are available from 2012 to 2016 on a monthly basis, with a resolution of 15-arc seconds - approximately $500 \mathrm{~m} \times 500 \mathrm{~m}$ tiles near the equator. For this paper, the raw data are aggregated to the district level, on a quarterly basis. Nighttime light is measured in Nanowatts/ $\mathrm{cm}^{2} /$ steradian.

\subsection{Formal economic activity}

Formal sector activity $Y^{F}$ is proxied through the number of active formal firms. Admittedly, formal firms have different sizes, and the ones for which data are available are likely to be among the largest ones. However, previous research suggests that larger formal firms are more likely to be impacted by conflict (Blumenstock et al., 2018). It follows that the observed change in the number of active formal firms overestimates the actual change in the overall economic activity. The net effect of these size and impact biases is unclear. In the absence of more information, it is assumed here that the relative change in formal economic activity $y^{F}$ is proportional to the relative change in the number of formal firms for which data are available.

The number of active formal firms is computed from a list of organizations that signed up for plans with multiple phones belonging to the same account. Public and non-profit organizations are excluded from this list, whereas multiple accounts from the same organization are consolidated into one. This results in a sample of 2,300 private firms covering 125,000 subscribers. Whether a firm is active is inferred from call detail records from all the phones registered under the corresponding corporate subscriber account. Call records contain the identity of the parties involved in the communication, as well as the timing of the communication and the location of the antenna where the call was initiated. The raw data were provided by a major mobile phone operator in Afghanistan and processed by Blumenstock et al. (2018). For this paper, the data were made available at the district level, on a monthly basis, for the period from April 2013 to April 2016. Formal firms with active cell phone traffic are measured per 1,000 inhabitants.

\subsection{Illicit economic activity}

The land surface devoted to opium poppy cultivation is used to estimate Illicit economic activity $Y^{O}$. It is recognized that poppy yields per hectare may vary across different parts of the country and over time. Yields could also decline as the cultivated surface increases, and more marginal land is used. However, the relevant margin in this case is not between cultivated and uncultivated land, but between land devoted to poppies and land devoted to wheat, with both being similar in terms of their agricultural potential (Keohler and Zuercher, 2007). Given the absence of detailed information on poppy yields across land plots, the paper assumes that the relative change in illicit economic activity $y^{A}$ is proportional to the relative change in the land surface devoted to opium cultivation. 
The data on land use are generated by the Ministry of Counter Narcotics (MCN) of Afghanistan in collaboration with the United Nations Office on Drugs and Crime (UNODC). The extent of opium poppy cultivation is assessed on an annual basis through a methodology that combines field work with remote sensing techniques. The latter are needed because field work is dangerous, given the security conditions on the ground and the illegal nature of the crop. Image interpretation of geo-referenced ground and aerial photography allows to generate digital maps of poppy fields (UNODC, 2007). The data on opium poppy cultivation used for this study are at the district level, for the period from 2007 to 2016 (UNODC, 2016 and 2017), measured in hectares per 1,000 inhabitants.

\subsection{Conflict intensity}

The intensity of conflict $C$ is derived from the number of killings, a metric associated with terrorist attacks generated by the GTD. This is a comprehensive source produced by the National Consortium for the Study of Terrorism and Responses to Terrorism, at the United States Department of Homeland Security Center of Excellence. Data on casualties for Afghanistan are available from May 1973 to December 2016. The raw data are georeferenced and available on a monthly basis; for this paper, they are aggregated at the district level. The intensity of conflict is defined as the number of killings and normalized by their standard deviation across the sample.

Alternatives sources of data based on primary sources exist. One example of this type of data is Significant Activities (SIGACTS), a rich database declassified by the United States Central Command for years 2008 to 2014 (Trebbi, 2019). Compared to it, the GTD is less rich in detail and relies on more indirect sources - such as news and intelligence reports. However, the GTD is useful in that it captures reasonably well visible surges in conflict, and it spans a longer number of years.

\subsection{Control variables}

Information on the presence of international and Afghan combat troops $-T^{W}$ and $T^{A}$, respectively - comes from the NATO ISAF placemat for each Regional Military Command (NATO, 2018). Placemats report province-level information on the number of ISAF troops by the contributing nations and on the localization of Provincial Reconstruction Teams (PRTs). Placemat issues also include information on the number of Afghan National Army (ANA) troops and on ISAF and ANA major units. Although information on PRTs is systematically reported, information on ISAF major units at the provincial level is only available from 2011 onwards. Combat troops are measured per 1,000 inhabitants in the province.

Foreign aid $D$ is proxied by development assistance commitments. The data come from the Development Assistance Database (DAD), the main publicly available source of information on development assistance in Afghanistan. Data are available by donor and sector, at the provincial level. They can be disaggregated into security-related aid and other forms of aid. Foreign aid is measured in constant US\$ per quarter per 1,000 inhabitants, at 2010 prices.

Summary statistics for the variables used in the empirical analysis are reported in Table 1. During the period considered in this paper, Afghan districts have an average nighttime light 
Table 1 Summary statistics

\begin{tabular}{lrrrrc}
\hline Variable & N & Mean & Min & Max & Std. Dev. \\
\hline Nighttime light (nanowatts) & 5,970 & 0.68 & 0.00 & 89.43 & 5.14 \\
$\begin{array}{l}\text { Active formal firms (per 1,000 } \\
\text { inhabitants) }\end{array}$ & 3,159 & 1.12 & 0.01 & 18.71 & 1.68 \\
$\begin{array}{l}\text { Poppy cultivation (hectares per } \\
\text { 1,000 inhabitants) }\end{array}$ & 3,582 & 6.73 & 0.00 & 416.5 & 27.20 \\
Killings (per 1,000 inhabitants) & 5,970 & 0.06 & 0.00 & 6.81 & 0.22 \\
$\begin{array}{l}\text { ISAF troops (per 1,000 inhabitants) } \\
\text { ANA troops (per 1,000 inhabitants) }\end{array}$ & 646 & 2.66 & 0.00 & 38.73 & 5.46 \\
$\begin{array}{l}\text { Security-related aid (USD per quarter } \\
\text { per 1,000 inhabitants) }\end{array}$ & 646 & 119 & 0.00 & 16,555 & 878 \\
$\begin{array}{l}\text { Other aid (USD per quarter per 1,000 } \\
\text { inhabitants) }\end{array}$ & 646 & 15,492 & 0.00 & 242,573 & 27,538 \\
\hline
\end{tabular}

ANA, Afghan National Army; ISAF, International Security Assistance Force.

intensity of 0.68 nanowatts, 1.2 active formal firms, 6.7 land hectares devoted to poppy cultivation per 1,000 inhabitants. On average, a district experiences 0.06 killings per 1,000 inhabitants per quarter. On average, a province hosts 2.6 international troops and 4.6 Afghan troops per 1,000 inhabitants. It also receives US $\$ 15,611$ in foreign aid per 1,000 inhabitants per quarter, of which US\$119 is for security and the rest for other forms of aid. However, these averages hide considerable variation.

\section{Results}

The results of the estimation for overall, formal, and illicit economic activity are presented in Figure 3A-C, respectively. Several variants of Eq. (5) are reported in each of the Tables 1-6 in Annex. The preferred specification depicted in Figure 3 appears in the fifth column. This specification separates international troops from Afghan troops and security-related aid from other aid.

Conflict has a negative effect on overall economic activity up to two quarters after a surge in the number of casualties. An increase in conflict by one a standard deviation is associated with reduction in nighttime light intensity by about $0.8 \%$ and $1.7 \%$ during the following two quarters respectively. The magnitude of this impact is stable across specifications. Given that the elasticity of aggregate economic activity to nighttime light is estimated at 0.25 , the relative change of the former when conflict increases by one standard deviation is approximately $0.4 \%$ $(=0.25 \times 1.7)$.

The effect is much stronger in the case of formal economic activity. A one-standard deviation increase in the conflict indicator is associated with a $4.9 \%$ reduction in the number of formal firms active in the following quarter. The effect remains negative in the following quarters, but the estimates are not statistically significant. This estimate is in line with the $6.4 \%$ decline 1 month after the surge in conflict reported in Blumenstock et al. (2018).

Finally, conflict boosts the amount of land devoted to opium cultivation. The estimated coefficients are positive in all quarters. They are statistically significant for the second quarter after a surge in conflict, when opium poppy cultivation increases by an estimated $6.3 \%$. These 
Figure 3 Response estimates of conflict on Economic Activity. (A) Conflict and nighttime light. (B) Conflict and active formal firms. (C) Conflict and land devoted to poppy cultivation.

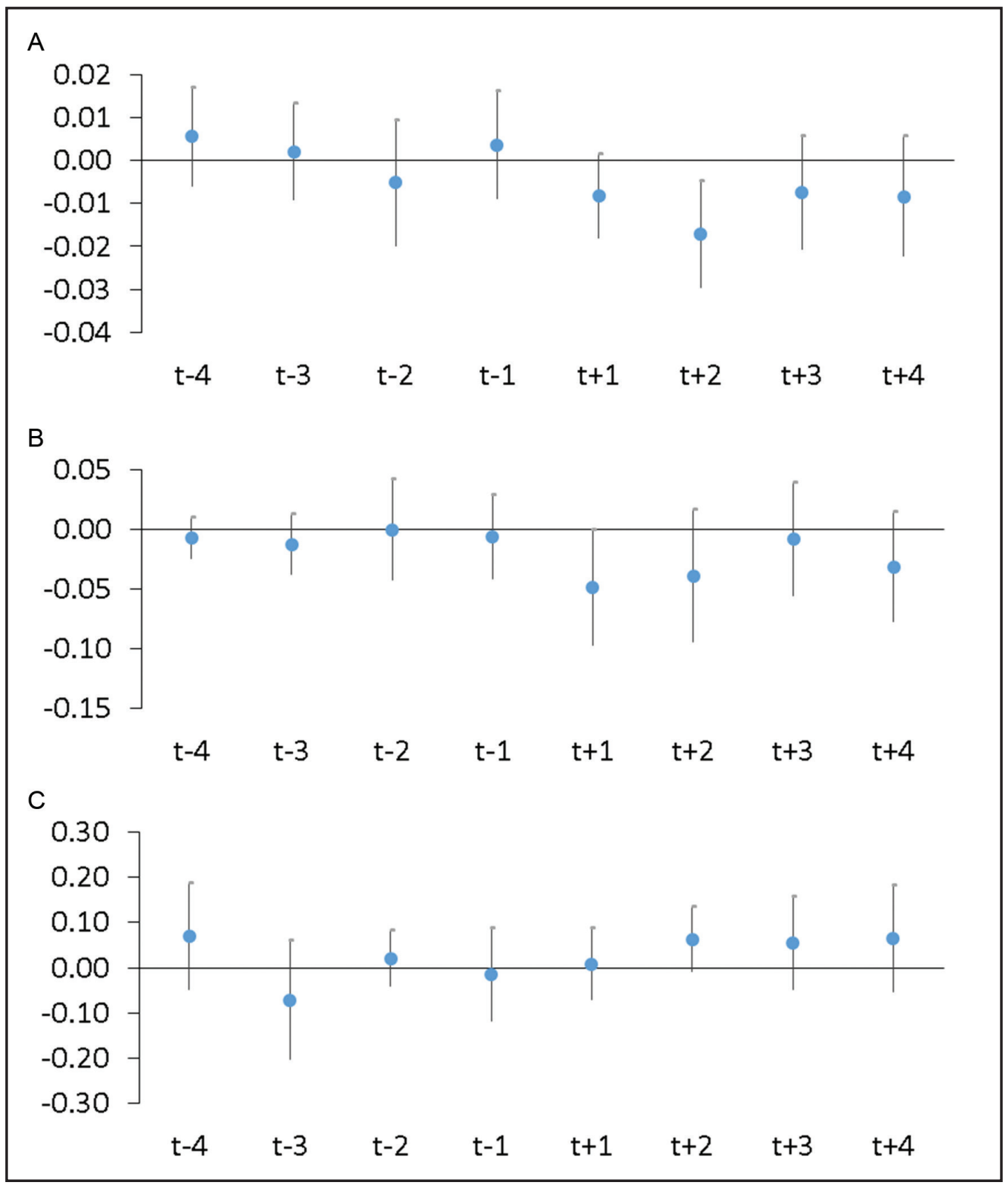

Note: Coefficients from regressing log (sum of lights per area), log (active formal firms per 1,000 inhabitants) and log (Poppy cultivation per 1,000 inhabitants) on lead and lags of conflict, controlling for district and time fixed effects, troops' presence and aid. Coefficients for $t-4$ to $t-1$ come from regressions (A4-A6), while coefficients for $t+1$ to $t+4$ come from regressions ( $A 1-A 3)$. Coefficient $t-1$ refers to the lead $(t+1)$ estimate. Conversely coefficient $t+1$ refers to the lag $(\mathrm{t}-1)$ estimate. Confidence intervals in whiskers are derived from district-clustered standard errors.

two estimated effects (4.9\% and 6.3\%) apply to formal and illicit economic activity, respectively, given the assumption that activity is proportional to the chosen indicator in both cases.

The significance of these findings is not entirely driven by the choice of standard errors in the estimation of Eq. (5). Both district clustered and robust standard errors yield similar results for the variables of interest, though there is a slight loss in precision with the former. Results with robust standard errors are available upon request. 
As a placebo test, Eq. (5) is estimated with leads rather than lags. The results, presented in Figure 3, suggest that leads causalities are not related to current economic activity at any level of statistical significance (see Tables 4-6 in Annex for details). These findings comfort causal interpretation of the main results.

The estimated coefficients on control variables are plausible.

The findings are similar if the indicators for combat troops and for foreign aid are normalized by corresponding standard deviation across the sample, like the way the conflict indicator is defined. The results of the estimation when using these alternative measures are available on request.

These findings suggest that conflict has important consequences for the structure of economic activity. The impact of a surge in conflict-related casualties is much stronger on formal and illicit activities than on overall economic activity. This is shown in Figure 4, which traces the

Figure 4 The impact of a surge in conflict on economic activity. (A) Temporary surge in conflict. (B) Permanent surge in conflict.

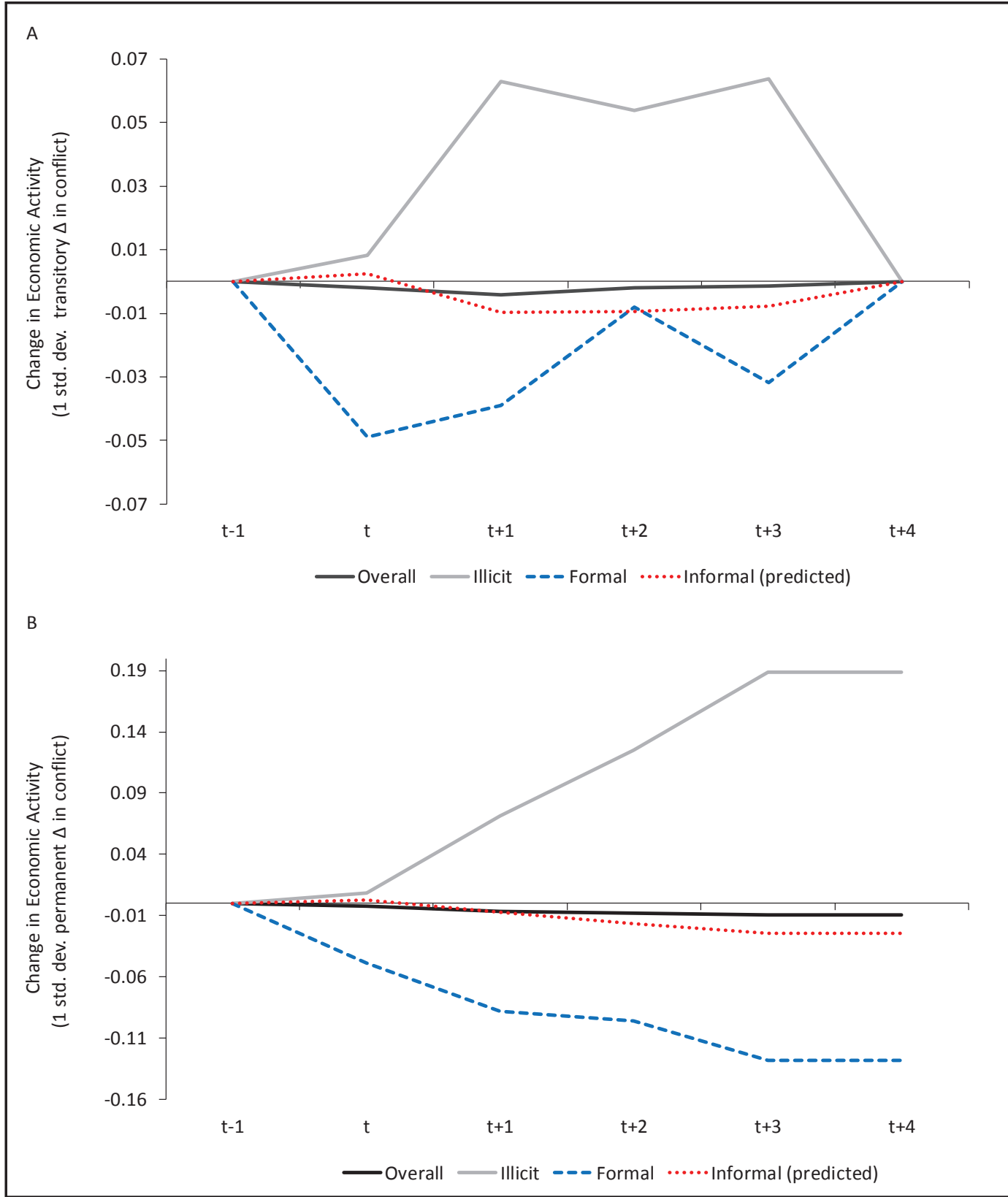


evolution of aggregate, formal, and illicit economic activity based on the estimated coefficients in our preferred specifications and the assumed 0.25 elasticity of aggregate economic activity to nighttime light intensity. Both panels in this figure are computed for an increase in conflict-related casualties by one standard deviation. In panel 3A the shock lasts for one quarter only, whereas in panel 3B it continues over time. This figure also shows the predicted impact on informal economic activity based on Eq. (6) and the estimated sectoral weights in total economic activity.

\section{Conclusion}

There is a comprehensive literature that focuses on the impact of conflict on the wellbeing of the population, considering indicators that range from health status to poverty. However, when it comes to economic activity the available estimates give a disproportionate weight to the formal sector. And this is despite informal and illicit activities being common, if not predominant, in conflict settings.

Data availability partly explains this bias. Aggregate indicators such as GDP tend to underestimate informal sector activities, and to exclude illicit activities. However, conflict studies are increasingly relying on innovative approaches that capture broad economic activity through remote sensing and other techniques (Min et al., 2013). Disaggregated indicators from non-traditional sources, from housing prices to construction permits to mobile phone traffic from registered firms, also refer to formal markets and organizations.

This paper considers the impact of conflict across formal, informal, and illicit activities simultaneously. The proposed methodology is firmly anchored in the literature, although it pays special attention to the dynamic structure of conflict impacts, and it controls for other variables that have been shown to affect economic activity in conflict settings. The main innovation of the paper comes from the reliance on non-traditional sources of data with a high degree of spatial granularity. Thus, nighttime light intensity is used to measure economic activity at the aggregate level, mobile phone traffic from registered firms for the formal sector, and the land surface devoted to poppy cultivation for illicit activities.

The results suggest that the main impact of conflict is not as much on aggregate economic activity as it is on its composition. Conflict escalation is associated with a major drop-in formal sector activity, an increase in its informal sector counterpart, and a surge in illicit activities. Therefore, assessments that focus on indicators giving a disproportionate weight to the formal sector tend to overestimate the impact of conflict on economic activity.

This finding should not be interpreted as downplaying the adverse consequences of conflict. A change in the composition of economic activity, from formal to informal and illicit, could have important indirect effects. The formal sector provides jobs that tend to be better than those in the rest of the economy and is the source of the tax revenue needed to pay for social services. Illicit activities are likely to have negative externalities, from greater insecurity to higher corruption. Through the change in the structure of the economy, a small decline in aggregate economic activity could still be associated with a major decline in the well-being of the population.

The impact of conflict on the structure of the economy also has potential policy implications. If conflict undermines formal sector activity, efforts to improve the business environment for formal sector firms become less effective. The results in this paper rather call for efforts to make the informal sector more productive, and more attractive relative to illicit activities. 


\section{Declarations}

\section{Availability of data and Materials}

With the sole exception of data on corporate mobile records, all the datasets used in this study are publicly available dataset products. They can be obtained from the corresponding author on reasonable request.

Data on corporate mobile records used in this study are not publicly available and as per agreement cannot be shared without permission of Blumenstock, J., Ghani, T., Herskowitz, S., Kapstein, E. B., Scherer, T., and Toomet, O. (2018).

\section{Conflict of Interests}

All authors are with the World Bank. The findings, interpretations, and conclusions expressed in this paper are entirely those of the authors. They do not necessarily represent the views of the International Bank for Reconstruction and Development and its affiliated organizations, or those of the Executive Directors of the World Bank or the governments they represent.

The authors listed immediately below have no conflicts of interest to declare; all co-authors have seen and agree with the contents of the manuscript and there is no financial interest to report-

- Virgilio Galdo

- Gladys Lopez-Acevedo

- Martin Rama

\section{Funding}

All authors are with the World Bank. This study is part of a larger effort by the World Bank to provide open access to its research and contribute to development policy discussions around the world.

\section{Authors' contributions}

Virgilio Galdo performed data curation, formal analysis, and software-related processes; Gladys Lopez-Acevedo and Martin Rama performed conceptualization; and all authors contributed toward formal analysis and drafting of the manuscript.

\section{Acknowledgments}

The authors are grateful to Tarek Ghani and Ethan Kapstein for providing access to an aggregated version of their dataset of detailed call records from Afghanistan. They are also grateful to Claudia Nassif and Tobias Haque for insightful comments on a previous version of the paper, and to Rucheta Singh for excellent research support.

\section{References}

Abadie, A.; J. Gardeazabal (2003): The Economic Costs of Conflict: A Case Study of the Basque Country. American Economic Review 93(1), 113-132. doi:10.1257/000282803321455188.

Acemoglu, D.; T. A. Hassan; J. Robinson (2011): Social Structure and Development: A Legacy of the Holocaust in Russia. Quarterly Journal of Economics 126(2), 895-946. doi:10.1093/qje/qjr018.

Bazzi, S.; R. A. Blair; C. Blattman; O. Duber; M. Gudgeon; R. M. Peck (2019): The Promise and Pitfalls of Conflict Prediction: Evidence from Colombia and Indonesia. NBER Working Paper 25980. Cambridge, MA: National Bureau of Economic Research. doi:10.3386/w25980.

Berman, E.; J. Felter; E. Kapstein, E. Troland (2013): Predation, Taxation, Investment and Violence: Evidence from the Philippines. NBER Working Paper 19266. Cambridge, MA: National Bureau of Economic Research. doi:10.3386/w19266.

Besley, T.; H. Mueller (2012): Estimating the Peace Dividend: The Impact of Violence on House Prices in Northern Ireland. American Economic Review 102(2), 810-833. doi:10.1257/aer.102.2.810.

Beyer, R. C. M.; E. Chhabra; V. Galdo; M. G. Rama (2018): Measuring Districts' Monthly Economic Activity from Outer Space. Policy Research Working Paper 8523. Washington, DC: The World Bank.

Blattman, C.; E. Miguel (2010): Civil War. Journal of Economic Literature 48(1), 3-57. doi:10.1257/jel.48.1.3.

Blumenstock, J.; G. Cadamuro; R. On (2015): Predicting Poverty and Wealth from Mobile Phone Metadata. Science 350(6264), 1073-1076. doi:10.1126/science.aac4420.

Blumenstock, J.; T. Ghani; S. Herskowitz; E. B. Kapstein; T. Scherer; O. Toomet (2018): Insecurity and Industrial Organization: Evidence from Afghanistan. Policy Research Working Paper 8301. Washington, DC.: The World Bank. 
Ciarli, T.; C. Kofol, C. Menon (2015): Business as Unusual. An Explanation of the Increase of Private Economic Activity in High-Conflict Areas in Afghanistan. SERC Discussion Papers 0182. London: Spatial Economics Research Centre.

Colier, P. (1999): On the Economic Consequences of Civil War. Oxford Economic Papers 51(1), 168-183. doi:10.1093/oep/51.1.168

De Groot, O. J.; C. Bozzoli; T. Brück (2015): The Global Economic Burden of Violent Conflict. Household in Conflict Network (HiCN) Working Paper 199. Brighton: Institute of Development Studies at Sussex.

Donaldson, D.; A. Storeygard (2016): The View from Above: Applications of Satellite Data in Economics. Journal of Economic Perspectives 30(4), 171-198. doi:10.1257/jep.30.4.171

Elvidge, C. D.; K. Baugh; M. Zhizhin; F. C. Hsu; T. Ghosh (2017): VIIRS Night-Time Lights. International Journal of Remote Sensing 38(21), 5860-5879. doi:10.1080/01431161.2017.1342050.

Floreani, V. A.; G. Lopez-Acevedo; M. Rama (2016): Conflict and Poverty in Afghanistan's Transition. Policy Research Working Paper 7864. World Bank, Washington, DC: The World Bank.

Goodhand, J. (2008): Corrupting or Consolidating the Peace? The Drugs Economy and Post-Conflict Peacebuilding in Afghanistan. International Peacekeeping 15(3), 405-423. doi:10.1080/13533310802058984.

GTD. (2016): Global Terrorism Database, University of Maryland National Consortium for the Study of Terrorism and Responses to Terrorism. https://www.start.umd.edu/gtd/

Henderson, J. V.; A. Storeygard; D. N. Weil (2012): Measuring Economic Growth from Outer Space. American Economic Review 102(2), 994-1028. doi:10.1257/aer.102.2.994.

Koehler, J.; C. Zürcher (2007): Statebuilding, Conflict and Narcotics in Afghanistan: The View from below. International Peacekeeping 14(1), 62-74. doi:10.1080/13533310601114269.

Lind, J. T.; K. O. Moene; F. Willumsen (2014): Opium for the Masses? Conflict-Induced Narcotics Production in Afghanistan. Review of Economics and Statistics 96(5), 949-966. doi:10.1162/REST_a_00418.

Looney, R. (2006): Economic Consequences of Conflict: The Rise of Iraq's Informal Economy. Journal of Economic Issues 40(4), 991-1007. doi:10.1080/00213624.2006.11506971

Min, B.; K. M. Gaba; O. F. Sarr; A. Agalassou (2013): Detection of Rural Electrification in Africa Using DMSP-OLS Night Lights Imagery. International Journal of Remote Sensing 34(22), 8118-8141. doi:10.1 080/01431161.2013.833358.

NATO (North Atlantic Treaty Organization) (2018): Resolute Support Mission Placements Archive 2007-2018. https://www.nato.int/cps/en/natolive/107995.htm.

Pei, T.; S. Sobolevsky; C. Ratti; S. L. Shaw; T. Li; C. Zhou (2014): A New Insight into Land Use Classification Based on Aggregated Mobile Phone Data. International Journal of Geographical Information Science 28(9), 1988-2007. doi:10.1080/13658816.2014.913794.

Singh, P. (2013): Impact of Terrorism on Investment Decisions of Farmers: Evidence from the Punjab Insurgency. Journal of Conflict Resolution 57(1), 143-168. doi:10.1177/0022002712464850.

SIGAR (Special Inspector General for Afghanistan Reconstruction). (2018): Private Sector Development and Economic Growth: Lessons from the U.S Experience in Afghanistan.

Stepanova, E. (2012): Illicit Drugs and Insurgency in Afghanistan. Perspectives on Terrorism 6(2), 4-18.

Trebbi, F. (2019): Quantitative Approaches to Violence, Small Wars, and Insurgencies. NBER Reporter 3, 11-13.

UNODC (2007, 2016, 2017): Afghanistan Opium Survey. New York: United Nations Office on Drugs and Crime.

UNAMA (2019): Afghanistan Protection of Civilians in Armed Conflicts Annual Report 2018. Kabul: United Nations Assistance Mission in Afghanistan.

World Bank. (2005): Afghanistan - State Building, Sustaining Growth, and Reducing Poverty. Washington DC: The World Bank.

World Bank (2017): Growth out of the Blue. South Asia Economic Focus. Washington DC: The World Bank.

World Bank (2018): Afghanistan to 2030: Economic Development Under Fragility. Washington DC: The World Bank.

World Bank (2020): Fragility and Conflict: On the Frontlines of the Fight against Poverty. Washington, DC: The World Bank. 


\section{Annex}

Table A1 Conflict and nighttime light

\begin{tabular}{|c|c|c|c|c|c|}
\hline & \multicolumn{5}{|c|}{ log (sum of lights per area) } \\
\hline & (1) & (2) & (3) & (4) & (5) \\
\hline \multirow[t]{2}{*}{ Conflicit $_{t-1}$} & $-0.0110^{\star \star}$ & $-0.00833^{\star}$ & $-0.00825^{\star}$ & $-0.00826^{\star}$ & $-0.00821^{\star}$ \\
\hline & $(0.00488)$ & $(0.00499)$ & $(0.00499)$ & $(0.00500)$ & $(0.00496)$ \\
\hline \multirow[t]{2}{*}{ Conflicit $_{t-2}$} & $-0.0203^{\star \star \star}$ & $-0.0173^{\star \star \star}$ & $-0.0173^{\star \star \star}$ & $-0.0172^{\star \star \star}$ & $-0.0172^{\star \star \star}$ \\
\hline & $(0.00659)$ & $(0.00632)$ & $(0.00632)$ & $(0.00631)$ & $(0.00631)$ \\
\hline \multirow[t]{2}{*}{ Conflicit $_{t-3}$} & -0.0103 & -0.00742 & -0.00751 & -0.00744 & -0.00749 \\
\hline & $(0.00764)$ & $(0.00676)$ & $(0.00676)$ & $(0.00675)$ & $(0.00675)$ \\
\hline \multirow[t]{2}{*}{ Conflicit $_{\mathrm{t}-4}$} & -0.00835 & -0.00836 & -0.00837 & -0.00838 & -0.00839 \\
\hline & $(0.00792)$ & $(0.00713)$ & $(0.00712)$ & $(0.00712)$ & $(0.00710)$ \\
\hline \multirow[t]{2}{*}{ Troops $_{t-1}$} & & $0.0211^{\star \star \star}$ & & $0.0212^{\star \star \star}$ & \\
\hline & & $(0.00455)$ & & $(0.00453)$ & \\
\hline \multirow[t]{2}{*}{$\mathrm{ISAF}_{\mathrm{t}-1}$} & & & $0.0217^{\star \star \star}$ & & $0.0215^{\star \star \star}$ \\
\hline & & & $(0.00476)$ & & $(0.00473)$ \\
\hline \multirow[t]{2}{*}{$\mathrm{ANA}_{\mathrm{t}-1}$} & & & -0.00943 & & 0.00251 \\
\hline & & & $(0.0758)$ & & $(0.0763)$ \\
\hline \multirow[t]{2}{*}{$\mathrm{AID}_{\mathrm{t}-1}$} & & $4.83 e-07^{\star \star \star}$ & $4.91 \mathrm{e}-07^{\star \star \star}$ & & \\
\hline & & $(1.85 e-07)$ & $(1.84 \mathrm{e}-07)$ & & \\
\hline \multirow[t]{2}{*}{ Security $_{t-1}$} & & & & $1.12 \mathrm{e}-05^{\star \star}$ & $1.10 \mathrm{e}-05^{\star \star}$ \\
\hline & & & & $(4.81 e-06)$ & $(4.81 \mathrm{e}-06)$ \\
\hline \multirow[t]{2}{*}{ Other aid t-1 $_{1}$} & & & & $4.40 e-07^{\star \star}$ & $4.45 \mathrm{e}-07^{\star \star}$ \\
\hline & & & & $(1.85 e-07)$ & $(1.83 e-07)$ \\
\hline District fixed effects & Yes & Yes & Yes & Yes & Yes \\
\hline Time fixed effects & Yes & Yes & Yes & Yes & Yes \\
\hline Observations & 5,970 & 5,970 & 5,970 & 5,970 & 5,970 \\
\hline Adj. R2 & 0.994 & 0.994 & 0.994 & 0.994 & 0.994 \\
\hline
\end{tabular}

District-clustered standard errors in parentheses.

${ }^{\star} p<0.10$.

${ }^{\star *} p<0.05$.

${ }^{* \star *} p<0.01$

ANA, Afghan National Army; ISAF, International Security Assistance Force. 
Table A2 Conflict and active formal firms

\begin{tabular}{|c|c|c|c|c|c|}
\hline & \multicolumn{5}{|c|}{$\log$ (active formal firms per 1,000 inhabitants) } \\
\hline & (1) & (2) & (3) & (4) & (5) \\
\hline \multirow[t]{2}{*}{ Conflicit $_{\mathrm{t}-1}$} & $-0.0512^{\star}$ & $-0.0488^{\star \star}$ & $-0.0490^{\star \star}$ & $-0.0489^{\star \star}$ & \\
\hline & $(0.0271)$ & $(0.0247)$ & $(0.0247)$ & $(0.0246)$ & $(0.0246)$ \\
\hline \multirow[t]{2}{*}{ Conflicit $_{\mathrm{t}-2}$} & -0.0401 & -0.0388 & -0.0388 & -0.0390 & -0.0390 \\
\hline & $(0.0303)$ & $(0.0284)$ & $(0.0283)$ & $(0.0284)$ & $(0.0283)$ \\
\hline \multirow[t]{2}{*}{ Conflicit $_{t-3}$} & -0.00931 & -0.00819 & -0.00792 & -0.00852 & -0.00819 \\
\hline & $(0.0250)$ & $(0.0243)$ & $(0.0242)$ & $(0.0243)$ & $(0.0242)$ \\
\hline \multirow[t]{2}{*}{ Conflicit $_{\mathrm{t}-4}$} & -0.0338 & -0.0318 & -0.0316 & -0.0320 & -0.0318 \\
\hline & $(0.0251)$ & $(0.0236)$ & $(0.0235)$ & $(0.0237)$ & $(0.0235)$ \\
\hline \multirow[t]{2}{*}{ Troops $_{t-1}$} & & 0.0264 & & 0.0264 & \\
\hline & & $(0.0264)$ & & $(0.0264)$ & \\
\hline \multirow[t]{2}{*}{ ISAF $_{t-1}$} & & & 0.0239 & & 0.0230 \\
\hline & & & $(0.0257)$ & & $(0.0256)$ \\
\hline \multirow[t]{2}{*}{ ANA $_{t-1}$} & & & 0.172 & & 0.224 \\
\hline & & & $(0.196)$ & & $(0.209)$ \\
\hline \multirow[t]{2}{*}{$A D_{t-1}$} & & $-1.42 \mathrm{e}-06^{\star \star}$ & $-1.42 \mathrm{e}-06^{\star \star}$ & & \\
\hline & & $(6.70 e-07)$ & $(6.72 e-07)$ & & \\
\hline \multirow[t]{2}{*}{ Security $_{t-1}$} & & & & $1.83 e-05^{\star \star \star}$ & $2.09 \mathrm{e}-05^{\star \star \star}$ \\
\hline & & & & $(6.39 e-06)$ & $(7.92 \mathrm{e}-06)$ \\
\hline \multirow[t]{2}{*}{ Other aid $_{\mathrm{t}-1}$} & & & & $-1.56 \mathrm{e}-06^{\star \star}$ & $-1.58 \mathrm{e} 06^{\star \star}$ \\
\hline & & & & $(6.89 e-07)$ & $(6.90 e-07)$ \\
\hline District fixed effects & Yes & Yes & Yes & Yes & Yes \\
\hline Time fixed effects & Yes & Yes & Yes & Yes & Yes \\
\hline Observations & 3,159 & 3,159 & 3,159 & 3,159 & 3,159 \\
\hline Adj. R2 & 0.835 & 0.836 & 0.836 & 0.836 & 0.836 \\
\hline
\end{tabular}

District-clustered standard errors in parentheses.

${ }^{\star} p<0.10$.

${ }^{\star *} p<0.05$.

${ }^{\star \star \star} p<0.01$.

ANA, Afghan National Army; ISAF, International Security Assistance Force. 
Table A3 Conflict and land devoted to poppy cultivation

\begin{tabular}{|c|c|c|c|c|c|}
\hline & \multicolumn{5}{|c|}{ log (Poppy cultivation per 1,000 inhabitants) } \\
\hline & (1) & (2) & (3) & (4) & (5) \\
\hline \multirow{2}{*}{ Conflicit $_{\mathrm{t}-1}$} & 0.00054 & 0.000385 & 0.0107 & -0.00158 & 0.00817 \\
\hline & $(0.0395)$ & $(0.0395)$ & $(0.0397)$ & $(0.0395)$ & $(0.0398)$ \\
\hline \multirow[t]{2}{*}{ Conflicit $_{t-2}$} & $0.0640^{\star}$ & $0.0613^{\star}$ & $0.0640^{\star}$ & $0.0603^{*}$ & $0.0630^{\star}$ \\
\hline & $(0.0365)$ & $(0.0365)$ & $(0.0369)$ & $(0.0365)$ & $(0.0369)$ \\
\hline \multirow[t]{2}{*}{ Conflicit $_{t-3}$} & 0.045 & 0.0429 & 0.053 & 0.045 & 0.0539 \\
\hline & $(0.0530)$ & $(0.0528)$ & $(0.0525)$ & $(0.0526)$ & $(0.0524)$ \\
\hline \multirow[t]{2}{*}{ Conflicit $_{\mathrm{t}-4}$} & 0.0674 & 0.0667 & 0.0626 & 0.0676 & 0.0637 \\
\hline & $(0.0614)$ & $(0.0610)$ & $(0.0593)$ & $(0.0610)$ & $(0.0595)$ \\
\hline \multirow[t]{2}{*}{ Troops $_{t-1}$} & & -0.00704 & & -0.00729 & \\
\hline & & $(0.00910)$ & & $(0.00903)$ & \\
\hline \multirow[t]{2}{*}{$\mathrm{ISAF}_{\mathrm{t}-1}$} & & & 0.0105 & & 0.00877 \\
\hline & & & $(0.0124)$ & & $(0.0122)$ \\
\hline \multirow[t]{2}{*}{ ANA $_{t-1}$} & & & $-0.0478^{\star \star}$ & & $-0.0444^{\star \star}$ \\
\hline & & & $(0.0186)$ & & $(0.0187)$ \\
\hline \multirow[t]{2}{*}{$\operatorname{AID}_{\mathrm{t}-1}$} & & $-5.10 e-06^{\star \star}$ & $-4.79 e-06^{\star \star}$ & & \\
\hline & & $(2.41 \mathrm{e}-06)$ & $(2.42 \mathrm{e}-06)$ & & \\
\hline \multirow[t]{2}{*}{ Security $_{\mathrm{t}-1}$} & & & & $-0.000274^{\star \star \star}$ & $-0.000233^{\star \star}$ \\
\hline & & & & $(9.41 e-05)$ & $(9.14 e-05)$ \\
\hline \multirow[t]{2}{*}{ Other aid $_{\mathrm{t}-1}$} & & & & $-5.05 e-06^{\star \star}$ & $-4.77 e-06^{\star \star}$ \\
\hline & & & & $(2.41 \mathrm{e}-06)$ & $(2.42 e-06)$ \\
\hline District fixed effects & Yes & Yes & Yes & Yes & Yes \\
\hline Time fixed effects & Yes & Yes & Yes & Yes & Yes \\
\hline Observations & 3,582 & 3,582 & 3,582 & 3,582 & 3,582 \\
\hline Adj. R2 & 0.835 & 0.836 & 0.836 & 0.836 & 0.836 \\
\hline
\end{tabular}

District clustered standard errors in parentheses.

${ }^{\star} p<0.10$.

${ }^{\star \star} p<0.05$.

${ }^{* * *} p<0.01$.

ANA, Afghan National Army; ISAF, International Security Assistance Force. 
Table A4 Conflict and nighttime light (placebo test)

\begin{tabular}{|c|c|c|c|c|c|}
\hline & \multicolumn{5}{|c|}{ log (sum of lights per area) } \\
\hline & (1) & (2) & (3) & (4) & (5) \\
\hline \multirow[t]{2}{*}{ Conflicit $_{t+1}$} & -0.000553 & 0.00363 & 0.00357 & 0.00365 & 0.00359 \\
\hline & $(0.00782)$ & $(0.00638)$ & $(0.00636)$ & $(0.00639)$ & $(0.00638)$ \\
\hline \multirow[t]{2}{*}{ Conflicit $_{t+2}$} & -0.00941 & -0.00527 & -0.00538 & -0.00514 & -0.00525 \\
\hline & $(0.00774)$ & $(0.00738)$ & $(0.00739)$ & $(0.00739)$ & $(0.00740)$ \\
\hline \multirow{2}{*}{ Conflicit $_{t+3}$} & -0.00223 & 0.00213 & 0.00205 & 0.00224 & 0.00216 \\
\hline & $(0.00642)$ & $(0.00572)$ & $(0.00573)$ & $(0.00571)$ & $(0.00572)$ \\
\hline \multirow[t]{2}{*}{ Conflicit $_{t+4}$} & 0.00366 & 0.00552 & 0.00544 & 0.00560 & 0.00553 \\
\hline & $(0.00638)$ & $(0.00588)$ & $(0.00587)$ & $(0.00588)$ & $(0.00587)$ \\
\hline \multirow[t]{2}{*}{ Troops $_{t-1}$} & & $0.0164^{\star \star \star}$ & & $0.0164^{\star \star \star}$ & \\
\hline & & $(0.00392)$ & & $(0.00392)$ & \\
\hline \multirow[t]{2}{*}{ ISAF $_{t-1}$} & & & $0.0172^{\star \star \star}$ & & $0.0172^{\star \star \star}$ \\
\hline & & & $(0.00398)$ & & $(0.00397)$ \\
\hline \multirow[t]{2}{*}{ ANA $_{t-1}$} & & & $0.0573^{\star}$ & & $0.0594^{\star}$ \\
\hline & & & $(0.0345)$ & & $(0.0345)$ \\
\hline \multirow[t]{2}{*}{$A D_{t-1}$} & & $1.19 \mathrm{e}-06$ & $1.02 \mathrm{e}-06$ & & \\
\hline & & $(9.56 e-07)$ & $(9.71 e-07)$ & & \\
\hline \multirow[t]{2}{*}{ Security $_{t-1}$} & & & & $1.27 \mathrm{e}-05^{\star \star \star}$ & $1.29 \mathrm{e}-05^{\star \star \star}$ \\
\hline & & & & $(4.85 e-06)$ & $(4.79 e-06)$ \\
\hline \multirow[t]{2}{*}{ Other aid $_{\mathrm{t}-1}$} & & & & $9.39 e-07$ & $7.54 \mathrm{e}-07$ \\
\hline & & & & $(9.81 e-07)$ & $(9.97 e-07)$ \\
\hline District fixed effects & Yes & Yes & Yes & Yes & Yes \\
\hline Time fixed effects & Yes & Yes & Yes & Yes & Yes \\
\hline Observations & 5,572 & 5,572 & 5,572 & 5,572 & 5,572 \\
\hline Adj. R2 & 0.993 & 0.994 & 0.994 & 0.994 & 0.994 \\
\hline
\end{tabular}

District-clustered standard errors in parentheses.

${ }^{\star} p<0.10$.

${ }^{\star \star} p<0.05$.

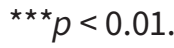

ANA, Afghan National Army; ISAF, International Security Assistance Force. 
Table A5 Conflict and active formal firms (placebo test)

\begin{tabular}{|c|c|c|c|c|c|}
\hline & \multicolumn{5}{|c|}{$\log$ (active formal firms per 1,000 inhabitants) } \\
\hline & (1) & (2) & (3) & (4) & (5) \\
\hline \multirow[t]{2}{*}{ Conflicit $_{t+1}$} & -0.00843 & -0.00643 & -0.00645 & -0.00650 & -0.00654 \\
\hline & $(0.0189)$ & $(0.0182)$ & $(0.0181)$ & $(0.0182)$ & $(0.0181)$ \\
\hline \multirow[t]{2}{*}{ Conflicit $_{t+2}$} & -0.00230 & -0.000640 & -0.000756 & -0.000623 & -0.000808 \\
\hline & $(0.0200)$ & $(0.0215)$ & $(0.0215)$ & $(0.0216)$ & $(0.0215)$ \\
\hline \multirow[t]{2}{*}{ Conflicit $_{t+3}$} & -0.0147 & -0.0122 & -0.0126 & -0.0123 & -0.0128 \\
\hline & $(0.0123)$ & $(0.0130)$ & $(0.0129)$ & $(0.0129)$ & $(0.0128)$ \\
\hline \multirow[t]{2}{*}{ Conflicit $_{t+4}$} & -0.00947 & -0.00736 & -0.00757 & -0.00736 & -0.00769 \\
\hline & $(0.00771)$ & $(0.00869)$ & $(0.00861)$ & $(0.00874)$ & $(0.00864)$ \\
\hline \multirow[t]{2}{*}{ Troops $_{t-1}$} & & 0.0198 & & 0.0196 & \\
\hline & & $(0.0193)$ & & $(0.0193)$ & \\
\hline \multirow[t]{2}{*}{ ISAF $_{t-1}$} & & & 0.0181 & & 0.0169 \\
\hline & & & $(0.0189)$ & & $(0.0189)$ \\
\hline \multirow[t]{2}{*}{ ANA $_{t-1}$} & & & 0.135 & & 0.207 \\
\hline & & & $(0.168)$ & & $(0.192)$ \\
\hline \multirow[t]{2}{*}{$A I D_{t-1}$} & & $-2.55 e-07$ & $-7.21 e-08$ & & \\
\hline & & $(9.50 e-07)$ & $(1.03 e-06)$ & & \\
\hline \multirow[t]{2}{*}{ Security $_{t-1}$} & & & & $1.51 \mathrm{e}-05^{\star \star}$ & $1.92 \mathrm{e}-05^{\star \star}$ \\
\hline & & & & $(6.01 e-06)$ & $(8.79 e-06)$ \\
\hline \multirow[t]{2}{*}{ Other aid $_{\mathrm{t}-1}$} & & & & $-8.04 e-07$ & $-6.43 e-07$ \\
\hline & & & & $(9.84 \mathrm{e}-07)$ & $(1.02 \mathrm{e}-06)$ \\
\hline District fixed effects & Yes & Yes & Yes & Yes & Yes \\
\hline Time fixed effects & Yes & Yes & Yes & Yes & Yes \\
\hline Observations & 2,673 & 2,673 & 2,673 & 2,673 & 2,673 \\
\hline Adj. R2 & 0.889 & 0.889 & 0.889 & 0.889 & 0.889 \\
\hline
\end{tabular}

District-clustered standard errors in parentheses.

${ }^{\star} p<0.10$.

${ }^{\star \star} p<0.05$.

${ }^{\star \star \star} p<0.01$.

ANA, Afghan National Army; ISAF, International Security Assistance Force. 
Table A6 Conflict and land devoted to poppy cultivation (placebo test)

\begin{tabular}{|c|c|c|c|c|c|}
\hline & \multicolumn{5}{|c|}{ log (Poppy cultivation per 1,000 inhabitants) } \\
\hline & (1) & $(2)$ & (3) & (4) & (5) \\
\hline \multirow[t]{2}{*}{ Conflicit $_{t+1}$} & -0.0248 & -0.0120 & -0.0123 & -0.0143 & -0.0151 \\
\hline & $(0.0514)$ & $(0.0519)$ & $(0.0521)$ & $(0.0522)$ & $(0.0524)$ \\
\hline \multirow[t]{2}{*}{ Conflicit $_{t+2}$} & 0.0140 & 0.0212 & 0.0212 & 0.0207 & 0.0207 \\
\hline & $(0.0305)$ & $(0.0319)$ & $(0.0319)$ & $(0.0319)$ & $(0.0319)$ \\
\hline \multirow[t]{2}{*}{ Conflicit $_{t+3}$} & -0.0537 & -0.0699 & -0.0705 & -0.0702 & -0.0718 \\
\hline & $(0.0775)$ & $(0.0664)$ & $(0.0669)$ & $(0.0666)$ & $(0.0669)$ \\
\hline \multirow[t]{2}{*}{ Conflicit $_{t+4}$} & 0.0668 & 0.0689 & 0.0687 & 0.0698 & 0.0695 \\
\hline & $(0.0551)$ & $(0.0595)$ & $(0.0595)$ & $(0.0597)$ & $(0.0599)$ \\
\hline \multirow[t]{2}{*}{ Troops $_{t-1}$} & & $-0.0250^{\star \star \star}$ & & $-0.0248^{\star \star \star}$ & \\
\hline & & $(0.00897)$ & & $(0.00893)$ & \\
\hline \multirow[t]{2}{*}{ ISAF $_{t-1}$} & & & $-0.0264^{\star}$ & & $-0.0287^{\star \star}$ \\
\hline & & & $(0.0136)$ & & $(0.0132)$ \\
\hline \multirow[t]{2}{*}{ ANA $_{t-1}$} & & & -0.0223 & & -0.0176 \\
\hline & & & $(0.0193)$ & & $(0.0193)$ \\
\hline \multirow[t]{2}{*}{$\operatorname{AID}_{\mathrm{t}-1}$} & & $-1.58 \mathrm{e}-05^{\star \star}$ & $-1.58 \mathrm{e}-05^{\star \star}$ & & \\
\hline & & $(6.61 e-06)$ & $(6.63 e-06)$ & & \\
\hline \multirow[t]{2}{*}{ Security $_{t-1}$} & & & & $-0.000682^{\star \star}$ & $-0.000704^{\star \star \star}$ \\
\hline & & & & $(0.000275)$ & $(0.000266)$ \\
\hline \multirow[t]{2}{*}{ Other aid $_{\mathrm{t}-1}$} & & & & $-1.56 \mathrm{e}-05^{\star \star}$ & $-1.58 \mathrm{e}-05^{\star \star}$ \\
\hline & & & & $(6.59 e-06)$ & $(6.59 e-06)$ \\
\hline District fixed effects & Yes & Yes & Yes & Yes & Yes \\
\hline Time fixed effects & Yes & Yes & Yes & Yes & Yes \\
\hline Observations & 3,184 & 3,184 & 3,184 & 3,184 & 3,184 \\
\hline Adj. R2 & 0.778 & 0.813 & 0.813 & 0.813 & 0.813 \\
\hline
\end{tabular}

District-clustered standard errors in parentheses.

${ }^{\star} p<0.10$.

${ }^{\star *} p<0.05$.

${ }^{\star * *} p<0.01$.

ANA, Afghan National Army; ISAF, International Security Assistance Force. 